(C) Economic Literature, Vol. XII (8-16), December 2014

\title{
An Analysis of Trend and Sources of Deficit Financing in Nepal
}

\author{
Deo Narayan Sutihar*
}

\begin{abstract}
Deficit financing has emerged as an important tool of financing government expenditure. In Nepal, the share of fiscal deficit to GDP ratio was $5.5 \%$ in FY $2010 / 11$ in compare to $3.6 \%$ of FY 2000/01. There are three sources of deficit financing i.e. foreign loan, domestic borrowing and cash balance and their shares to fiscal deficit have found 24.3\%, 85.7\% and -10.0\% respectively in FY 2010/11. The domestic borrowing to budget deficit was found to be very high. The fiscal deficit to expenditure ratio was maximum $30.3 \%$ in FY 2000/01 and minimum $16.8 \%$ in FY 2010/11 respectively. This exhibits that there was decreasing trend in ratio in the study period. The regression equation has been used to estimate the annual declining rate of fiscal deficit to expenditure ratio. The estimates of the annual average and annual declining rate of deficit/expenditure ratio have been found to be $26.64 \%$ and $0.846 \%$ respectively. From the result, it is obvious that fiscal deficit/expenditure ratio has been decreased by $0.846 \%$ annually during the period of 11 years. This trend exhibits that Nepal will try to announce balanced budget in the near future. From the statistical analysis, the value of autocorrelation is found to be 0.427 and its $d$-statistic has been estimated 1.003, which not significant at 5\% level of significance. Thus, the analysis justifies that there is no positive autocorrelation among error terms in the study period.
\end{abstract}

Key words: fiscal deficit, deficit financing, fiscal indicators, trends and growth, autocorrelation, d-statistic.

\section{BACKGROUND}

The term deficit financing is used to denote the direct addition to gross national expenditure through budget deficit, whether the deficits are on revenue or of capital account. The essence of such policy lies, therefore, in government spending in excess of the revenue it receives in the shape of taxes, earning of state enterprises, loans from the public, deposits, funds, other miscellaneous sources. The government may cover either by running down its accumulated balances or by borrowing from the banking system (Shrestha and Adhikari, 2012: 248).

Deficit financing has emerged as an important tool of financing government expenditure. It can fill up the gap caused by the excess of government expenditure over its receipts. It can be financed in two ways: first, borrowing by the government from foreign loan and domestic loan, which is called debt financing and second, fiscal deficit can be financed by printing new money is called money financing of budget deficit (Ahuja, 2012:652).

\footnotetext{
* Mr. Sutihar is Associate Professor at Department of Economics, Prithvi Narayan Campus, T. U., Pokhara.
} 
If the government spends more than it raises in taxation it will have to borrow money. If it borrows by selling government securities, including national savings certificates to the non-bank private sector (non-bank firms and general public) it will be using existing money. The purchasers will be likely to draw money out of their bank deposits. So, the rise in liquid assets resulting from increased government spending will be matched by an equal fall in liquid assets as money is withdrawn. However, if a budget deficit is financed by borrowing from the commercial banks or the central bank, money will increase. When a government borrows from its central bank it spends cheques drawn on bank. This spending increases commercial banks' liquid assets and that will increase their ability to lend. Commercial banks will be able to lend more if the government borrows from loans by selling them short-term government securities. This is because these securities count as liquid assets and so can be used as the basis for loans (Bamford and Grant, 2011: 216).

The term of deficit financing is used as an excess of expenditure incurred by the government over its current income financed through public loans and the creation of new money. It is also used as the scheme of the government expenditure in which the deficit is met by utilization the cash balances with central bank. Excess of expenditure over current income is met from the sources of borrowing from the central bank, withdrawal of cash balances, borrowing from the commercial banks and issue of new currency by the government or printing of new notes. In developing countries like Nepal deficit financing is adopted to meet budgetary deficit and resources needed to implement developing planning. The resources needed to implement different types of development projects cannot meet by taxation and borrowing from the public only. The gap between expenditure and income is fulfilled by foreign aid and deficit financing ( Dahal, et.al., 2014:308).

A proper method of financing budget deficit is borrowing by the government which issues bonds and sells it to the public through financial intermediaries such as banks, is called bond financing of budget deficit. The fiscal deficit, the result of imbalance between expenditure and non-debt resources, has been financed foreign loan, domestic borrowing and cash balance from the central bank (MOF, 2008: 34).

It is evident from the contraction in economic growth rate in the recent past that the overall economic expansion has been affected adversely due to slackness in the development activities. Therefore, to increase the development activities, the challenge is to mobilize revenue at least to the level that could meet the recurrent and principal payment expenditures. Similarly, there is a need to allocate best possible amount of resources for the capital outlay and give special priority to control unproductive and wasteful expenses. This will give a positive boost for the economic expansion and help to create sustainable base for the realization of higher economic development (MOF, 2008: 35).

The main objective of this study is to show the fiscal deficit/GDP ratio, fiscal deficit/expenditure ratio $\&$ the share of foreign loan, domestic borrowing and cash balance to fiscal deficit. Similarly, it aims to estimate the annual declining rate of fiscal deficit to expenditure ratio and to test the declining rate of this ratio is significant or not. The study is very much helpful to those people who want to get knowledge about the statistical estimation of a variable related to time series and use of statistical tools. However, the findings of the study should be cautiously used because the 
analysis is made only for 11 years. The data before 2000/01 have not been considered to analyze due to time constraints and unavailable data.

\section{DATA AND METHODS}

This article is based on the secondary data annually published by the Government of Nepal. The Economic Survey (FY 2007/08, FY 2010/11 of Nepal are the only sources of obtaining statistical data for the present study (Table 1).

The data have been analyzed with the help of different statistical tools such as ratio, percentage, equation of straight line for estimating the annual declining rate of fiscal deficit/expenditure ratio. The standard error of estimate, $t$-statistic of parameters ' $a$ ' and ' $b$ ', coefficient of determination $\mathrm{R}^{2}$, adjusted coefficient of determination $\overline{\mathrm{R}}^{2}$, coefficient of autocorrelation and Durbin-Watson statistic have been calculated.

The estimating equation of straight line has been used in the form of $Y=a+b X$, where "a" and ' $b$ ' are parameters \& ' $a$ ' stands for the annual average of fiscal deficit/expenditure ratio and ' $b$ ' represents annual declining rate of fiscal deficit/expenditure ratio. For these two parameters, the following two normal equations have been used:

$$
\begin{aligned}
& \sum \mathrm{Y}=\mathrm{na}+\mathrm{b} \sum \mathrm{X} \\
& \sum \mathrm{XY}=\mathrm{a} \sum \mathrm{X}+\mathrm{b} \sum \mathrm{X}^{2} \\
& S_{y . x}=\sqrt{\frac{\sum e^{2}}{n-2}} \text { has been used to find the standard error of estimate, where, } \mathrm{n} \text { and } \mathrm{k} \text { stand }
\end{aligned}
$$

for number of years and parameters respectively.

The statistical hypotheses for parameters 'a' and ' $b$ ' have been set up and tested. The t-statistic has been used to test the significance these parameters. The null and alternative hypotheses for the parameter 'a' have been tested for the significance of annual average of deficit/expenditure ratio. Hypotheses for Parameter 'a'

Null hypothesis, H0: $a=0$, i.e. annual average of deficit/expenditure ratio is not significant at $5 \%$ level of significance with $n-2$ degrees of freedom. Alternative hypothesis $\mathrm{H}_{1}$ : a $>0$, i.e. annual average of deficit/expenditure ratio is significant at $5 \%$ level of significance with $n-2$ degrees of freedom. The t-statistic is also calculated. The null and alternative hypotheses for the parameter 'b' have been used for the significance of annual decrease in deficit/expenditure ratio.

Hypotheses for Parameter ' $b$ '

Null hypothesis, $\mathrm{H}_{0}: \mathrm{b}=0$, i.e. declining rate of deficit /expenditure ratio is not significant at $5 \%$ level of significance with $\mathrm{n}-2$ degrees of freedom.

Alternative hypothesis, $\mathrm{H}_{1}: \mathrm{b}<0$, i.e. declining rate of deficit /expenditure ratio is significant at $5 \%$ level of significance with n-2 degrees of freedom. Under null/alternative hypotheses, the t-test has been used. 
Coefficient of determination $\mathrm{R}^{2}$ and adjusted coefficient of determination $\overline{\mathrm{R}}^{2}$ have also been computed by using the following method:

$$
R^{2}=1-\frac{\sum e^{2}}{\sum y^{2}} \text { and } \bar{R}^{2}=1-\frac{\sum e^{2}}{\sum y^{2}} \times \frac{n-1}{n-k} .
$$

Similarly, the first order autocorrelation among error terms has been calculated by using the formula: $\rho=\frac{\sum_{i=2}^{t} e_{t} e_{t-1}}{\sum_{i=1}^{t} e_{t}{ }^{2}}$ and the D-W statistic has been used to test the following hypothesis: Null hypothesis, $H_{0}: \rho=0$, i.e. there is no presence of autocorrelation among error terms. Alternative hypothesis, $H_{A}: \rho>0$, i.e. there is presence of autocorrelation among error terms.

The test statistic under null hypothesis is

$$
d=\frac{\sum_{i=2}^{t}\left(e_{t}-e_{t-1}\right)^{2}}{\sum_{i=1}^{t} e_{t}^{2}}
$$

This statistic measures the correlation between each error and the error for the time period immediately preceeding one (Sutihar, 2010: 578).

\section{RESULTS AND DISCUSSION}

The present study evaluates the fiscal deficit to GDP ratio, which ranges from 2.9\% in FY 2003/04 to $5.5 \%$ in FY 2000/01. This ratio has been decreasing from FY 2000/01 to FY 2003/04 and then increasing up to FY 2008/09. Similarly, fiscal deficit to expenditure ratio fluctuates from $15.9 \%$ in FY $2029 / 10$ to $30.3 \%$ in FY 2000/01. This ratio has been found decreasing from FY 2000/01 to FY 2004/05 then after increasing gradually up to FY 2007/08 (Table 1). There are three sources of deficit financing in our country namely foreign loan, domestic borrowing and cash balance. The foreign loan to fiscal deficit ratio varies from $20.0 \%$ to $51.3 \%$. It shows that the minimum share of this ratio was $20.0 \%$ in FY $2008 / 09$ and the maximum is $51.3 \%$ in FY 2004/05. Similarly, the domestic loan to fiscal deficit deviates from $28.9 \%$ to $85.7 \%$. It is obvious that the minimum share of this ratio was $28.9 \%$ in FY 2000/01 and the maximum was $85.7 \%$ in FY 2010/11. Likewise, the cash balance to fiscal deficit ratio varies from $-10.0 \%$ to $43.0 \%$. It is clear that the minimum share of this ratio was $-10.0 \%$ in FY 2010/11 and the maximum was 43.07\% in FY 2008/09 (Table 1).

This study also estimates the average value and declining rate of deficit to expenditure ratio during 11 years. It has been estimated through the analysis of time series data of 11 years from FY 2000/01 to FY 2010/11. It is obvious that the annual average and declining rate of fiscal deficit to expenditure ratio during study period have been estimated to be $26.64 \%$ and $-0.846 \%$ respectively. This exhibits that fiscal deficit to expenditure ratio is decreasing by $0.846 \%$ per year (Annex 1 ). 
Table 1: GDP, Expenditure, Receipts, Deficit and Sources of Deficit Financing (Rs. in millions)

\begin{tabular}{lrrrrrrr}
\hline Fical Year & GDP & Expenditure & Receipts & Deficit & \multicolumn{3}{c}{ Sources of deficit financing } \\
\cline { 7 - 8 } & & & & & Foreign loan & $\begin{array}{r}\text { Domestic } \\
\text { loan }\end{array}$ & $\begin{array}{r}\text { Cash } \\
\text { balance }\end{array}$ \\
\hline & & & & & & & \\
$2000 / 01$ & 441519 & 79835.1 & 55647.0 & 24188.1 & 12044.0 & 7000.0 & 5144.1 \\
& & & & $(5.5)^{*}$ & $(49.8)^{\mathrm{a}}$ & $(28.9)^{\mathrm{b}}$ & $(21.3)^{\mathrm{c}}$ \\
$2001 / 02$ & 459443 & 80072.2 & 57131.6 & 22940.6 & 7698.7 & 8000.0 & 7241.9 \\
& & & & $(5.0)$ & $(33.6)$ & $(34.8)$ & $(31.6)$ \\
$2002 / 03$ & 492231 & 84006.1 & 67568.9 & 16437.2 & 4546.4 & 8880.0 & 3010.8 \\
& & & & $(3.3)$ & $(27.7)$ & $(54.4)$ & $(18.3)$ \\
$2003 / 04$ & 536749 & 89442.6 & 73614.4 & 15828.2 & 7629.0 & 5607.8 & 2591.4 \\
& & & & $(2.9)$ & $(48.2)$ & $(35.4)$ & $(16.4)$ \\
$2004 / 05$ & 589412 & 102560.4 & 84513.9 & 18046.5 & 9266.1 & 8938.1 & -157.7 \\
& & & & $(3.1)$ & $(51.3)$ & $(49.5)$ & $(-0.8)$ \\
$2005 / 06$ & 654055 & 110889.2 & 86109.6 & 24779.6 & 8214.3 & 11834.2 & 4731.1 \\
& & & & $(3.8)$ & $(33.1)$ & $(47.8)$ & $(19.1)$ \\
$2006 / 07$ & 727827 & 133604.6 & 103512.9 & 30091.7 & 10053.5 & 17892.3 & 2145.9 \\
& & & & $(4.1)$ & $(33.4)$ & $(59.5)$ & $(7.1)$ \\
$2007 / 08$ & 815658 & 161349.9 & 127943.2 & 37406.7 & 8979.9 & 24496.4 & 3930.4 \\
& & & & $(4.6)$ & $(24.0)$ & $(65.5)$ & $(10.5)$ \\
$2008 / 09$ & 988272 & 219662.0 & 169857.3 & 49804.7 & 9968.9 & 18417.1 & 21418.7 \\
& & & & $(5.0)$ & $(20.0)$ & $(37.0)$ & $(43.0)$ \\
$2009 / 10$ & 1193679 & 259689.1 & 218491.7 & 41197.4 & 11223.4 & 29914.0 & 60.0 \\
& & & & $(3.5)$ & $(27.2)$ & $(72.6)$ & $(0.2)$ \\
$2010 / 11$ & 1369430 & 295363.4 & 245741.2 & 49622.2 & 12075.6 & 42515.8 & -4969.1 \\
& & & & $(3.6)$ & $(24.3)$ & $(85.7)$ & $(-10.0)$ \\
\hline
\end{tabular}

Sources: Economic Survey, Fiscal Year 2007/08, Table 1.1; 1, Table 2.1; 13.

\& Economic Survey, Fiscal Year 2068/69, Nepali ed., Table 1.1: 1, Table 2.1; 13.

Notes: *The figures in bracket show fiscal deficit/GDP ratio (in \%).

a The figures in bracket show foreign loan /fiscal deficit ratio (in \%).

$b$ The figures in bracket show domestic loan /fiscal deficit ratio (in \%).

c The figures in bracket show cash balance /fiscal deficit ratio (in \%).

The falling trend of fiscal deficit/expenditure ratio line exhibits that deficit proportion to government expenditure of Nepal is decreasing continuously during the study period (Figure 1).

The standard error of estimate has been estimated 3.9783\%. Likewise, the standard error of parameters 'a' annual average and 'b' annual declining rate are $0.686 \%$ and $0.379 \%$ respectively.

The calculated value of $t_{(a)}$ is 38.826 . It is greater than the critical value of $t_{0.05}(9)=2.262$ (Two tailed test), which comprises that null hypothesis is rejected and alternative hypothesis is accepted at $5 \%$ level of significance with 9 degree of freedom. Therefore, it is concluded that annual average of deficit to expenditure ratio is significant.

But the calculated value of $\mathrm{t}_{(\mathrm{b})}$ has been found 2.232, which is less than the critical value of $\mathrm{t}_{0.05}(9)=2.262$ (Two tailed test). It justifies that null hypothesis is accepted at $5 \%$ level of significance with 9 degree of freedom. From the result, it is concluded that fiscal deficit to expenditure ratio is not significant, but it is decreasing by $0.846 \%$ annually during the study period. 
The coefficient of determination is 0.9712 . It shows that $97.12 \%$ of the total variation in deficit to expenditure ratio is explained by the variation in time variable. Similarly, the adjusted coefficient of determination is 0.9680 , which exhibits that $96.8 \%$ of the total variance in deficit/expenditure ratio is explained by the variance in time variable.

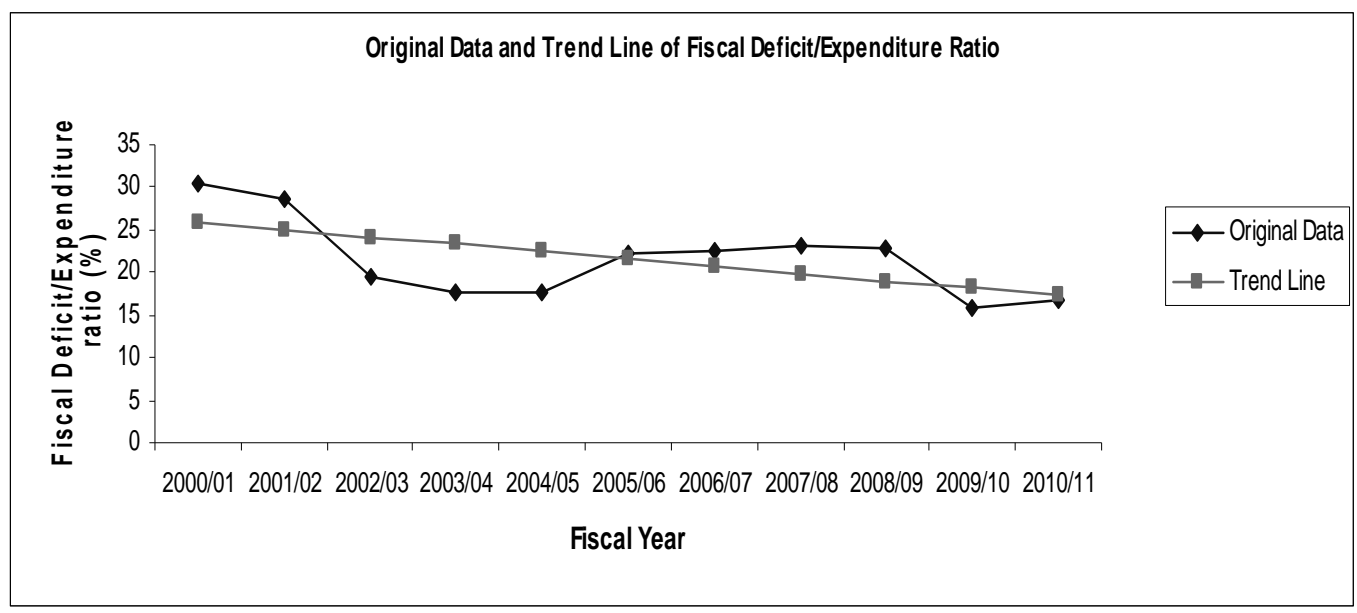

The coefficient of autocorrelation $(\rho)$ has been found to be 0.427 and its d-statistic has been estimated as 1.003 . This value lies between $d_{L}=0.937$ and $d_{U}=1.334$, i.e. $\left(d_{L}<d<d_{U}\right)$ at $5 \%$ level of significance with $k^{\prime}=1$ and $n=11$. Hence, the test is inconclusive. Therefore, it is concluded that there is presence of positive autocorrelation among error terms in the study period.

\section{CONCLUSION}

From the analysis of data, it is obvious that the share of fiscal deficit/GDP ratio is fluctuated from $2.9 \%$ to $5.5 \%$ during study period. The share of fiscal deficit/expenditure ratio has been found to vary from $15.9 \%$ to $30.3 \%$ in the same period. Annual growth rate of deficit/expenditure ratio is also found $-0.846 \%$, which indicates that this ratio is declining by Rs. 846 thousand per annum. The annual declining trend of fiscal deficit to expenditure ratio exhibits that the Government of Nepal will be able to prepare and announce the balanced budget in near future.

The coefficient of determination is 0.9712 . It shows that $97.12 \%$ of the total variation in deficit to expenditure ratio is explained by the variation in time variable. Similarly, the adjusted coefficient of determination is 0.9680 , which exhibits that $96.8 \%$ of the total variance in deficit/expenditure ratio is explained by the variance in time variable. The value of autocorrelation is found to be 0.427 and its d-statistic has been estimated 1.003, which is not significant at 5\% level of significance. Thus, the analysis exhibits that there is no positive autocorrelation among error terms in the study period. 


\section{REFERENCES}

Ahuja, H. L. (2012). Macroeconomics Theory and Policy, Eighteenth revised ed.New Delhi: S. Chand and Company Ltd.

Bamford, Colin and Susan Grant (2011). Economics, Second ed. Cambridge: Cambridge University Press.

Dahal, M. P. et.al. (2014). Macroeconomics. Kathmandu: Buddha Academic Publishers and Distributors Pvt. Ltd.

Ministry of Finance (2008). Economic Survey Fiscal Year 2007/08. Kathmandu: Government of Nepal.

Ministry of Finance (2069). Economic Survey Fiscal Year 2068/69, Nepali ed. Kathmandu: Government of Nepal.

Shrestha, R. G. and G. M. Adhikari (2012). Macroecnomics, Revised Fourth ed. Kathmandu: Asia Publication Pvt.Ltd'.

Sutihar, D. N. (2010). Quantiyative Techniques. Kathmandu: Pairavi Prakashan (Publishers and Distributors)

\section{Annex I}

Fiscal Deficit, Expenditure (Rs. In Million) and Calculation of Sum and Square Values

\begin{tabular}{|c|c|c|c|c|c|c|c|c|c|}
\hline Year & Deficit & Expenditure & $\begin{array}{c}\text { Deficit/ } \\
\text { Expenditure } \\
\text { ratio }(\%)(Y)\end{array}$ & $\begin{array}{l}\text { Time } \\
(\mathrm{X})\end{array}$ & $\mathrm{X}^{2}$ & $\mathrm{XY}$ & $\hat{\mathrm{Y}}$ & $e_{t}$ & $\mathrm{e}_{\mathrm{t}}^{2}$ \\
\hline $2000 / 01$ & 24188.1 & 79835.1 & 30.3 & 1 & 1 & 30.3 & 25.8 & 4.5 & 20.25 \\
\hline $2001 / 02$ & 22940.6 & 80072.2 & 28.6 & 2 & 4 & 57.2 & 24.9 & 3.7 & 13.69 \\
\hline $2002 / 03$ & 16437.2 & 84006.1 & 19.6 & 3 & 9 & 58.8 & 24.1 & -4.5 & 20.25 \\
\hline $2003 / 04$ & 15828.2 & 89442.6 & 17.7 & 4 & 16 & 70.8 & 23.3 & -5.6 & 31.36 \\
\hline $2004 / 05$ & 18046.5 & 102560.4 & 17.6 & 5 & 25 & 88.0 & 22.4 & -4.8 & 23.04 \\
\hline $2005 / 06$ & 24779.6 & 110889.2 & 22.3 & 6 & 36 & 133.8 & 21.6 & 0.7 & 0.49 \\
\hline $2006 / 07$ & 30091.7 & 133604.6 & 22.5 & 7 & 49 & 157.5 & 20.7 & 1.8 & 3.24 \\
\hline $2007 / 08$ & 37406.7 & 161349.9 & 23.2 & 8 & 64 & 185.6 & 19.9 & 3.3 & 10.89 \\
\hline $2008 / 09$ & 49804.7 & 219662.0 & 22.7 & 9 & 81 & 204.3 & 19.0 & 3.7 & 13.69 \\
\hline $2009 / 10$ & 41197.4 & 259689.1 & 15.9 & 10 & 100 & 159.0 & 18.2 & -2.3 & 5.29 \\
\hline \multirow[t]{2}{*}{$2010 / 11$} & 49622.2 & 295363.4 & 16.8 & 11 & 121 & 184.8 & 17.3 & -0.5 & 0.25 \\
\hline & & & $\begin{array}{l}\sum \mathrm{Y} \\
=237.2\end{array}$ & $\begin{array}{l}\sum X \\
=66\end{array}$ & $\begin{array}{l}\sum X^{2} \\
=506\end{array}$ & $\begin{array}{l}\sum X Y \\
=1330.1\end{array}$ & $\begin{array}{l}\sum \hat{\mathrm{Y}} \\
=237.2\end{array}$ & 0 & $\begin{array}{l}\sum e_{t}^{2} \\
=142.4 \\
4\end{array}$ \\
\hline
\end{tabular}

Source: Adapted and calculated from Table 1.

Regression equation of deficit/expenditure ratio $(\mathrm{Y})$ on time $(\mathrm{X})$ : $\mathrm{Y}=\mathrm{a}+\mathrm{bX}$

For the parameters ' $a$ ' and ' $b$ ', following two normal equations have been solved.

$$
\sum \mathrm{Y}=\mathrm{na}+\mathrm{b} \sum \mathrm{X} \text { and } \sum \mathrm{Y}=\mathrm{a} \sum \mathrm{X}+\mathrm{b} \sum \mathrm{X}^{2}
$$

After substituting the values: $237.2=11 \mathrm{a}+66 \mathrm{~b}$ and $1330.1=66 \mathrm{a}+506 \mathrm{~b}$

After solving these two equations, the values of ' $a$ ' and ' $b$ ' have been obtained and the estimated regression equation is $\hat{\mathrm{Y}}=26.64-0.846 \mathrm{X}$ 
$\mathrm{S}_{\mathrm{y} . \mathrm{x}}=\sqrt{\frac{\sum \mathrm{e}^{2}}{\mathrm{n}-2}}=3.9783, \operatorname{Se}(a)=\sqrt{\frac{\sum e^{2}}{n-2}\left[\frac{1}{n}+\frac{\bar{X}^{2}}{\sum x^{2}}\right]}=0.6801, \operatorname{Se}(b)=\sqrt{\frac{\sum e^{2}}{n-2}\left[\frac{\bar{X}^{2}}{\sum x^{2}}\right]}=0.3793$

$\sum \mathrm{x}^{2}=\sum \mathrm{X}^{2}-\left(\frac{\sum \mathrm{X}}{\mathrm{n}}\right)^{2}=110, \sum \mathrm{y}^{2}=\sum \mathrm{Y}^{2}-\left(\frac{\sum \mathrm{Y}}{\mathrm{n}}\right)^{2}=4941.5896, \sum e_{t}^{2}=\sum(Y-\hat{Y})^{2}=142.44$,

$\sum e_{t} e_{t-1}=60.77$ and $\sum\left(e_{t}-e_{t-1}\right)^{2}=142.84$

$\mathrm{t}_{(\mathrm{a})}=\frac{\mathrm{a}}{\operatorname{Se}(\mathrm{a})}=\frac{26.64}{0.6801}=38.826$ and $\mathrm{t}_{(\mathrm{b})}=\frac{\mathrm{b}}{\operatorname{Se}(\mathrm{b})}=\frac{-0.846}{0.3793}=-2.232$

Coefficient of determination: $\mathrm{R}^{2}=1-\frac{\sum \mathrm{e}^{2}}{\sum \mathrm{y}^{2}}=0.9712$,Adjusted coefficient of determination:

$\overline{\mathrm{R}}^{2}=1-\frac{\sum \mathrm{e}^{2} / \mathrm{n}-2}{\sum \mathrm{y}^{2} / \mathrm{n}-1}=0.9680, \sum \mathrm{y}^{2}=$ Total variation, $\sum \mathrm{e}^{2}=$ Unexplained variation

and $\sum \mathrm{y}^{2}-\sum \mathrm{e}^{2}=$ Explained variation

$\rho=\frac{\sum_{i=2}^{t} e_{t} e_{t-1}}{\sum_{i=1}^{t} e_{t}{ }^{2}}=\frac{60.77}{142.44}=0.427 \quad, \quad d=\frac{\sum_{i=2}^{t}\left(e_{t}-e_{t-1}\right)^{2}}{\sum_{i=1}^{t} e_{t}{ }^{2}}=\frac{142.84}{142.44}=1.003$ 